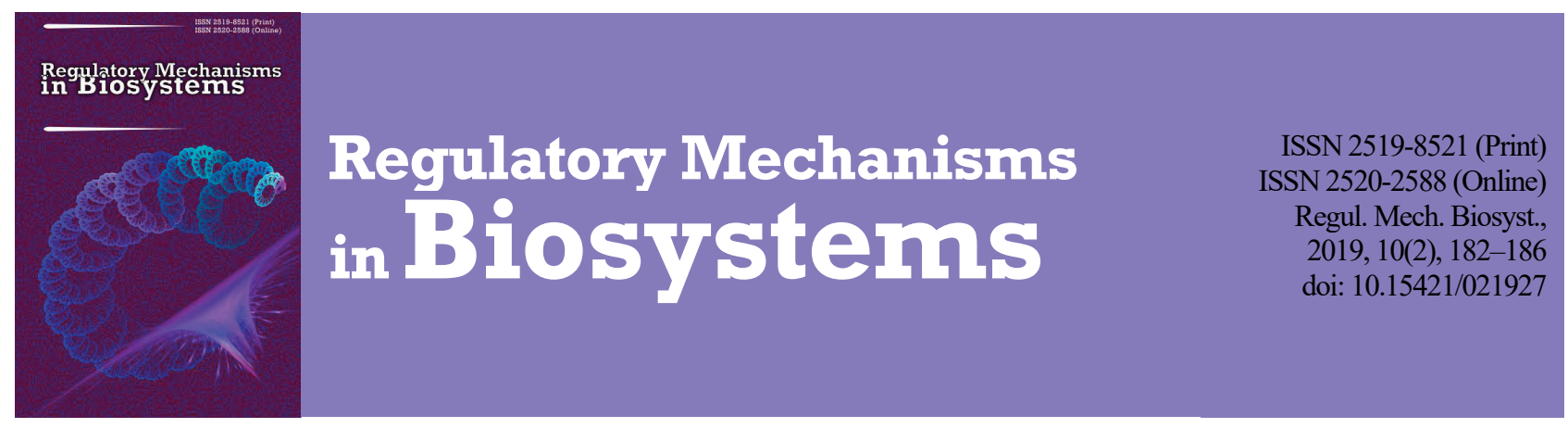

\title{
Biochemical parameters of blood in cows in latent course of leptospirosis
}

\author{
V. I. Holovakha*, A. O. Slyusarenko*, O. S. Petrenko**, N. I. Suslova*** \\ *Bila Tserkva National Agrarian University, Bila Tserkva, Ukraine \\ **SSRI of Laboratory Diagnostics and Veterinary-Sanitary Expertise, Kyiv, Ukraine \\ ***Dnipro State Agrarian and Economic University, Dnipro, Ukraine
}

Article info

Received 11.05.2019

Received in revised form 17.06.2019

Accepted 20.06.2019

Bila Tserkva National Agrarian University,

pl. Soborna, 8/1,

Bila Tserkva, 09117, Ukraine.

Tel.:+38-067-693-17-73.

E-mail:naukafutbol@i.ua

SSRI of Laboratory Diagnostics and Veterinary-Sanitary Expertise, Donetska st., 30 Kyiv, 03151, Ukraine.

Dnipro State Agrarian and Economic University, S. Efremov st., 25,

Dnipro, 49600, Ukraine.

Tel.:+38-050-908-98-45.

E-mail: suslova@ua.fm

Holovakha, V. I., Sliusarenko, A. O., Petrenko, O. S., \& Suslova, N. I. (2019). Biochemical parameters of blood in cows in latent course of leptospirosis. Regulatory Mechanisms in Biosystems, 10(2), 182-186. doi:10.15421/021927

Changes in the biochemical parameters of blood in cows in the latent course of leptospirosis have been studied by the results of the reaction of microagglutination (RMA). The dynamics of biochemical blood parameters is manifested by hyperproteinemia, dysproteinemia, hemolytic anemia, hyperbilirubinemia, intra- and extrahepatic cholestasis, hyperfermentemia, mineral metabolism disorders, in particular hypocalcemia, hypophosphatemia, indicating the development of hepatopathy which should be classified as hepatocholangitis. It was determined that the pathological process is manifested in all animals for the titer of antibodies to one or another Leptospira serovar. Significant changes from the side of the hepatobiliary system in infested cows for the antibody titer kabura equaling 1:100, polonica 1:200, ballum 1:100, szvajzak 1:100-1:200, bratislava 1:800 and in animals for the titers kabura of 1:100-1:200; polonium 1:100; szvajzak 1:100-1:200; ballum 1:100; bratislava 1:100-1:200. At leptospirosis caused by bratislava and ballum serovars, a disorder of the functional state of the hepatobiliary system, characterized by an increase in the level of total protein, bilirubin, AST, GGTP and ALP activity was diagnosed as the urea, calcium and phosphorus levels in blood decreased. In the case of the latent course of the disease caused by kabura, polonica, szvajzak, ballumand bratislava serovars, a probably higher concentration of bilirubin, activity of aminotransferases (AST and ALAT), GGTP and ALP was determined in comparison to clinically healthy animals. In cows, in the presence of antibody titers kabura 1:100, polonica 1:200, ballum 1:100, szvajzak 1:100-1:200; bratislava 1:800, in 22.2\% of cases, we recorded increase in the total protein against the background of dysproteinemia in $50.0-88.9 \%$ of animals, and increase in bilirubin in $78.6 \%$, and increase in the activity of blood serum enzymes (AST, ALAT, GGTP, ALP), and also hypocalcemia and hypophosphatemia in 33.3-100.0\%. The conducted studies indicate that in latent leptospirosis in cows, in addition to etiotropic therapy, one should include in the protocol the pharmacological correction preparations, which would contribute to the restoration of the functional state of the hepatobiliary system.

Keywords: hepatocholangitis; serovars of Leptospira; enzymes; reaction of microagglutination; hepatopathy; lactating cows.

\section{Introduction}

Leptospirosis is a worldwide zoonosis, with a wide range of hosts, including humans and animals, caused by Leptospira pathogenic spirochetes (Correia et al., 2018; Daud et al., 2018; Jaeger et al., 2018; Zarantonelli et al., 2018), which has a large number of serovars, similarity of which is essential for effective diagnosis (Arent et al., 2012; MughiniGras et al., 2013). The disease is common in most regions of the world, particularly in Latin America (Correia et al., 2018; Guedes et al., 2019), Oceania (Subharat et al., 2012; Dreyfus et al., 2018; Reichel et al., 2018), Southeast Asia (Chadsuthi et al., 2018; Shrestha et al., 2018).

The disease manifests in many species of animals: in cattle, buffalo, sheep, goats, deer, dogs, rodents, horses, and swine (Shiokawa et al., 2019). Leptospirosis has long been associated with occupational proximity to animals (rats and cattle) (Le Turnier \& Epelboin, 2018). In cattle, Leptospira causes an acute course in calves and a chronic course in cows, resulting in abortions (Libonati et al., 2018; Pinna et al., 2018; Rocha et al., 2018). It is transferred with urine of infected animals or water contaminated with the bacteria (Allan et al., 2018, Chadsuthi et al., 2018; Ferrer de Morais et al., 2018).

The distribution of leptospirosis in northeastern Brazil among cattle, sheep and goats was $50.5 \%, 40.5 \%$ and $34.6 \%$, respectively. It should be noted that in cattle the commonest were associations of hardjo and wolffi serovars and in goats and sheep - icterohaemorrhagiae associations (Campos et al., 2017). In the New Zealand region, the dominant serovar was hardjo, which was common among deer, cattle and sheep, respectively $42 \%, 53 \%$ and $54 \%$. Instead, the pomona serovar was detected in $7 \%, 5 \%$ and $0 \%$ respectively (Subharat et al., 2012). In the Caribbean region, the most numerous serovar found among cattle was mancarso, bratislava serovar among sheep, and hardjo among goats, 18\%, 10.4\%, $3.8 \%$ and $1.9 \%$ respectively (Shiokawa et al., 2019).

Currently, more than 250 serovars are known, based on the differences in the carbohydrate component of the bacterial lipopolysaccharide. Different serovars are adapted to certain wild and domestic species of animals that serve as their reservoir hosts. It is known that certain species of animals are vulnerable to certain serovars (Ayral et al., 2014; Tagliabue et al., 2016; Pratt et al., 2017) of leptospirosis infection. In cows of the Brazilian Amazon, the commonest serovar is sejro (Guedes et al., 2019). Signs of leptospirosis in humans are nonspecific at the initial stages: influenza-like syndrome, cough, thrombocytopenia, increased CPR (Le Turnier \& Epelboin, 2018). In humans in Nepal, the disease manifested as anorexia, rapid fatigue, hyperthermia, severe sweating and pain in the area of the spine. It should be noted that the disease manifested in men who kept goats (Shrestha et al., 2018).

The immune response to leptospirosis is serovar-specific. Since 26 antigen-dependent serovars are known, an animal can be infected with leptospirosis 26 times (Ko et al., 2009; Picardeau, 2017). The distribution of seropositivity of leptospirosis among bovine animals ranges from $13 \%$ (Rajala et al., 2017) to $81.7 \%$ (Daud et al., 2018). Due to the complex dynamic epidemiology of the disease in livestock, control regard- 
ing its diagnosis is controversial, especially in cattle in tropical climates (Martins \& Lilenbaum, 2017). In Ukraine, the dominant serovars of Leptospira in cattle are kabura $(12.4 \%)$, polonica $(9.5 \%)$, tarassovi (5.1\%) and bratislava (4.9\%) (Ukhovskyi et al., 2018). There are publications about hematological changes in animals with clinical manifestation of the disease. At the same time, we did not find out what changes occur in the biochemical parameters of blood in animals with different antibody titres (RMA) in available literature sources. Therefore, the purpose of the work was to study the biochemical parameters of blood in cows at sensitivity to different serotypes of Leptospira.

\section{Materials and methods}

The object of research were lactating cows of 3-7 years of age of black-spotted breed, which were divided into several groups: the firstclinically healthy $(\mathrm{n}=10)$; the second - in animals of this group antibodies were detected in the serogroups of Leptospira: bratislava 1:100 1:200, ballum 1:100-1:200 $(\mathrm{n}=12)$; the third - cows, in which, by the reaction of microagglutination (RMA), antibodies to the following serologic groups of Leptospira were found: kabura 1:100-1:200, polonica 1:100, szvajzak 1:100-1:200, ballum 1:100-1:200, bratislava 1:100 $1: 200(\mathrm{n}=14)$; the fourth - cows, in which antibodies to the following serologic groups of Leptospira were found: kabura 1:100, polonica 1:200, ballum 1:100, szvajzak 1:100-1:200, bratislava 1:800 $(\mathrm{n}=9)$. Biochemical monitoring of blood of cows was carried out using the Global Scientific reagents on the Stat Fax 1904+ device. Blood from cows was taken in test tubes in the morning before milking. After allowing it to settle (4-6 h), the blood was centrifuged at $3000 \mathrm{rpm}$ and blood serum was taken into test tubes. In the blood serum, we determined the total protein content (biuret reaction), urea (urease method), creatinine (modified Jaffe reaction); aminotransferase activity (AST and ALAT) kinetic method; alkaline phosphatase (ALP) - by the reaction of sodium hydrolysis of n-nitrophenyl phosphate; the content of calcium (with arsenazo reagent) and phosphorus (by the method of UV - detection of the phosphomolybdate complex) (reagents from Global Scientific Company). The activity of gamma-glutamyl transpeptidase (GGTP) was determined using the Szasz method (SPE reagents of Reagent, Dnipro, Ukraine).

In addition, for the determining dysproteinemia, we used coagulation tests - mercury-chloride sublimate (Greenstead) and formalin tests.

The statistical analysis of the obtained results was carried out using the Statistica 10 program (StatSoft Inc., USA, 2011). The probability of the difference between the selections was determined using ANOVA, considered significant at $\mathrm{P}<0.05$.

\section{Results}

In cows of all three experimental groups, there were no significant changes in the general condition. However, some had dullness and stiffness of the hair. Body temperature, respiratory frequency were within the limits of physiological fluctuations. At biochemical blood test, the following was determined. Content of total protein, which is one the indicators of functional condition of the liver, was within the physiological norm in all the cows of the experimental groups (second-fourth) (Table 1), but some of the cows of the second-fourth groups were observed to have hyperproteinemia. Most animals with hyperproteinemia were found in the third group (42.9\%), fewer in the fourth (22.2\%) and the second (16.7\%). Obviously, hyperproteinemia develops by activation of the immunological process, increase in the formation of immunoglobulins and pathological proteins - paraproteins. In addition, some of the cows of the second to fourth groups were observed to have hypoproteinemia. Most animals with low values of total protein $(<72 \mathrm{~g} / \mathrm{L})$ were found in the fourth and third groups, equaling $22.2 \%$ and $21.4 \%$, respectively, due to the disorder in the protein-synthesizing function of the liver protein-synthesizing.

It should be noted that in a significant proportion of the cows, dysproteinemia was observed - a disorder in the ratio between albumins and globulins (Table 2). The largest number of cows for which the Greenstead test was positive was observed in the fourth $(88.9 \%)$ and third (85.7\%) groups. The largest number of cows with positive formaline test was in the third group (78.6\%), and the least in the fourth
$(50 \%)$. In cows of the third group, its value was evaluated in "+" and "++", while in the fourth group it was evaluated in "+1+" and "+11+" (that is, sharply positive). At leptospirosis, the urea-forming function of hepatocytes decreases. According to conducted studies, the urea content in the blood serum was at a the lower level of the norm $(3.5 \mu \mathrm{mol} / \mathrm{L})$ on average for the groups (Table 2). The analysis of the obtained parameters in the groups showed that in a significant number of cows, the urea content was reduced. The low values of this component of the remaining nitrogen ( $\mathrm{RN}$ ) were found in $33.3 \%$ of cows from the second group, $50.0 \%$ of the third and $44.4 \%$ of the fourth experimental groups.

Table 1

Biochemical parameters of blood in cows

of the black-spotted breed with latent course of leptospirosis $(\mathrm{x} \pm \mathrm{SD})$

\begin{tabular}{|c|c|c|c|}
\hline Group of animals & $\begin{array}{c}\text { Total } \\
\text { protein, } \mathrm{g} / \mathrm{L}\end{array}$ & $\begin{array}{l}\text { Urea, } \\
\mu \mathrm{mol} / \mathrm{L}\end{array}$ & $\begin{array}{l}\text { Creatinine, } \\
\mu \mathrm{mol} / \mathrm{L}\end{array}$ \\
\hline The first: clinically healthy $(\mathrm{n}=10)$ & $75.7 \pm 1.65$ & $4.4 \pm 0.38$ & $98.2 \pm 2.97$ \\
\hline $\begin{array}{l}\text { The second experimental: } \\
\text { bratislava, ballum }(\mathrm{n}=12)\end{array}$ & $77.7 \pm 2.26$ & $3.8 \pm 0.31$ & $107.9 \pm 2.49$ \\
\hline $\begin{array}{l}\text { The third experimental: } \\
\text { kabura, polonica, szvajzak, } \\
\text { ballum, bratislava }(\mathrm{n}=14)\end{array}$ & $79.8 \pm 2.67$ & $3.8 \pm 0.47$ & $101.4 \pm 3.44$ \\
\hline $\begin{array}{l}\text { The fourth experimental: kabura, polo- } \\
\text { nica, ballum, szvajzak, bratislava }(\mathrm{n}=9)\end{array}$ & $79.0 \pm 3.00$ & $3.9 \pm 0.35$ & $105.6 \pm 2.85$ \\
\hline
\end{tabular}

Table 2

Parameters of colloidal-sedimentary reactions in cows

of black-and-white breed with latent course of leptospirosis $(x \pm S D)$

\begin{tabular}{|c|c|c|}
\hline Group of animals & Greenstead test & Formaline test \\
\hline The first: clinically healthy $(\mathrm{n}=10)$ & $1.72 \pm 0.030$ & - \\
\hline $\begin{array}{l}\text { The second experimental: } \\
\text { bratislava, ballum }(\mathrm{n}=12)\end{array}$ & $1.36 \pm 0.050^{* * *}$ & $+-+1+$ \\
\hline $\begin{array}{l}\text { The third experimental: } \\
\text { kabura, polonica, szvajzak, } \\
\text { ballum, bratislava }(\mathrm{n}=14)\end{array}$ & $1.31 \pm 0.068^{* * *}$ & $+-+1+$ \\
\hline $\begin{array}{l}\text { The fourth experimental: kabura, polo- } \\
\text { nica, ballum, szvajzak, bratislava }(\mathrm{n}=9)\end{array}$ & $1.31 \pm 0.076^{* * *}$ & $+\mathrm{H}+\mathrm{H}$ \\
\hline
\end{tabular}

Note: $* * *-\mathrm{P}<0.001$ compared to clinically healthy.

Another indicator of RN - creatinine, which is a marker of the filtration function of the kidneys, in all infected cows was normal. That is, changes from the side of the filtration function of the kidneys in animals of all three groups were not detected.

At leptospirosis, the cows suffer disorder of the pigmentary function of hepatocytes, indicator of which is the content of bilirubin in blood serum. According to our studies, the level of total bilirubin in cows in experimental groups was heightened (Table 3). In the cows of the second experimental group, the content of bile pigment was $8.6 \pm$ $1.19 \mu \mathrm{mol} / \mathrm{L}$ on average, which is three times higher than in the clinically healthy $(\mathrm{P}<0.05)$. A similar trend was also observed in animals of the third experimental group. The total bilirubin level in them was $8.2 \pm$ $0.77 \mu \mathrm{mol} / \mathrm{L}$ on average. Hyperbilirubinemia $(>6.0 \mu \mathrm{mol} / \mathrm{L})$ in these groups was determined in $75.0 \%$ and $78.6 \%$ of animals.

Table 3

Parameters of the activity of enzymes in cows of black-spotted breed with latent course of leptospirosis $(\mathrm{X} \pm \mathrm{SD})$

\begin{tabular}{|c|c|c|c|}
\hline Group of animals & $\begin{array}{c}\text { Total bilinubin, } \\
\mu \mathrm{mol} / \mathrm{L}\end{array}$ & $\begin{array}{l}\text { AST, } \\
\text { IU/L }\end{array}$ & $\begin{array}{l}\text { ALAT, } \\
\text { IU/L }\end{array}$ \\
\hline The first, clinically healthy $(\mathrm{n}=10)$ & $4.3 \pm 0.26$ & $51.0 \pm 3.65$ & $23.5 \pm 1.34$ \\
\hline $\begin{array}{l}\text { The second experimental: } \\
\text { bratislava, ballum }(\mathrm{n}=12)\end{array}$ & $8.6 \pm 1.19 * * *$ & $98.2 \pm 9.20 * *$ & $27.5 \pm 1.80$ \\
\hline $\begin{array}{l}\text { The third experimental: } \\
\text { kabura, polonica, szvajzak, } \\
\text { ballum, bratislava }(\mathrm{n}=14)\end{array}$ & $8.2 \pm 0.77 * * *$ & $86.1 \pm 4.30^{* *}$ & $27.2 \pm 1.17$ \\
\hline $\begin{array}{l}\text { The fourth experimental: } \\
\text { kabura,polonica, ballum, } \\
\text { szvajzak, bratislava }(\mathrm{n}=9)\end{array}$ & $6.4 \pm 0.74 * *$ & $86.9 \pm 4.77^{* *}$ & $30.0 \pm 1.73 * * *$ \\
\hline
\end{tabular}

In cows of the fourth group, the total bilirubin content was $6.4 \pm$ $0.74 \mu \mathrm{mol} / \mathrm{L}$ on average. Increased values of bile pigment were found in 
$77.8 \%$ of infected cows. A total of $22.2 \%$ of animals showed very low total bilirubin values $(0.34-0.41 \mu \mathrm{mol} / \mathrm{L})$. Consequently, hyperbilirubinemia is associated with increased erythrocyte hemolysis, excessive formation of total bilirubin, which is a rather toxic product, which primarily affects the cellular structure of hepatocytes. This is confirmed by indications for liver enzymes, in particular, aminotransferases (AST and ALAT). The activity of AST was heightened in all infected cows. In particular, its value in animals of the second group was $98.2 \pm 9.20 \mathrm{IU} / \mathrm{L}$, which is 1.9 times more than in the clinically healthy $(\mathrm{P}<0.01)$.

In the third and fourth groups, we also observed the hyperenzymemia AST, equaling $86.1 \pm 4.30$ and $86.9 \pm 4.77 \mathrm{IU} / \mathrm{L}$. It should be noted that increased values of AST were found in all infected cows. Unlike AST, the activity of another aminotransferase - ALAT has a different tendency. In the infected cows of the second and third groups, the values of enzyme activity did not differ from the values of clinically healthy ( $\mathrm{P}<0.05$; Table 3$)$. Only in the fourth group of cows, the activity of ALAT was higher compared to the clinically healthy. According to the analysis of the obtained parameters, increased activity of ALAT was determined in $16.7 \%$ of animals of the second, $14.3 \%$ in the third and $33.3 \%$ in the fourth group. Damage to the liver manifested by the development of intra- and extrahepatic cholestasis, to which the GGTP and ALP enzymes rapidly react (Table 4). In particular, GGTP is located in the "surface towards Bile canaliculus" that is membranes of hepatocytes and in bile duct cells. Its activity in hepatopathy increases earlier than AST, ALAT, and ALP.

\section{Table 4}

The activity of cholestatic enzymes (GGTP and ALP) in cows of black-spotted breed with latent course of leptospirosis $(x \pm S D)$

\begin{tabular}{|c|c|c|}
\hline Group of animals & GGTP, $\mu$ kat/L & ALP, IU/L \\
\hline The first: clinically healthy $(\mathrm{n}=10)$ & $0.41 \pm 0.043$ & $41.2 \pm 2.89$ \\
\hline $\begin{array}{l}\text { The second experimental: } \\
\text { bratislava, ballum }(\mathrm{n}=12)\end{array}$ & $1.15 \pm 0.116^{* * *}$ & $61.7 \pm 4.76^{* *}$ \\
\hline $\begin{array}{l}\text { The third experimental: kabura, polonica, } \\
\text { szvajzak, ballum, bratislava }(\mathrm{n}=14)\end{array}$ & $1.12 \pm 0.133 * * *$ & $77.8 \pm 9.14^{* *}$ \\
\hline $\begin{array}{l}\text { The fourth experimental: kabura, } \\
\text { polonica, ballum, szvajzak, bratislava }(\mathrm{n}=9)\end{array}$ & $1.01 \pm 0.153^{* *}$ & $63.1 \pm 4.51^{* *}$ \\
\hline
\end{tabular}

Note: $* *-\mathrm{P}<0.01 ; * * *-\mathrm{P}<0.001$ compared to clinically healthy.

The GGTP activity in cows in the second group was on average $1.15 \pm 0.116 \mu \mathrm{kat} / \mathrm{L}$, i.e. 2.8 times higher compared to the clinically healthy $(\mathrm{P}<0.001)$. Similar values of the enzyme were noted in the other groups (Table 4). Hyperenzymemia of GGTP ( $>0.6 \mu \mathrm{kat} / \mathrm{L}$ ) was determined in $91.7 \%, 78.6 \%$ and $77.8 \%$ of cows, respectively, of the second - fourth groups.

Cows of all experimental groups (second-fourth) had also on average increased activity of ALP, an enzyme which is located on the cell membrane and takes part in the transport of phosphorus. The activity of ALP is most often increased due to damage to hepatocytes and disorder of excretion of bile. Its activity, according to the results, in the infected cows was increased for the groups on average compared to clinically healthy $(\mathrm{P}<0.05$; Table 4). Hyperenzymemia of ALP was found in $33.3 \%, 57.1 \%$ and $55.6 \%$ of animals in the second - the fourth groups, respectively.

Therefore, increased activity of aminotransferases (AST and ALAT), gamma-glutamyltranspeptidase (GGTP), and alkaline phosphatase indicates the development of hepatopathy. In cows of all experimental groups (the second-fourth), we observed disorder of mineral metabolism. This applies, in particular, to calcium and phosphorus. The content of calcium in blood of cows of the second group tended to decrease, compared to the first, and on average equaled $2.26 \pm 0.103 \mathrm{mmol} / \mathrm{L}(\mathrm{P}<$ 0.1; Table 5). A similar tendency was found in other groups (Table 5). Hypocalcemia (below $2.5 \mathrm{mmol} / \mathrm{L}$ ) was observed in $66.7 \%, 78.6 \%$ and $44.4 \%$ of cows in the second - fourth groups.

Hypocalcemia is a consequence of the deficiency of vitamin D and its metabolites, in particular, 25-hydroxycholecalciferol (synthesized in hepatocytes) at hepatopathy. The content of another macro-element, phosphorus, in the groups was also on average below the minimum norm $(1.45 \mathrm{mmol} / \mathrm{L})$ (Table 5). Hypophosphatemia was determined in $66.7 \%, 64.3 \%$ and $66.7 \%$ of cows of the second - fourth groups, re- spectively. Reduced values of this macroelement in cows indicates the pathology of the liver in cows and indicate disorder in the processes of regulation of the acid-base homeostasis, carbohydrates, lipids and proteins in the body.

\section{Table 5}

Biochemical parameters of blood in cows

of black-spotted breed with latent course of leptospirosis $(x \pm S D)$

\begin{tabular}{lcc}
\hline \multicolumn{1}{c}{ Group of animals } & Ca, $\mathrm{mmol} / \mathrm{L}$ & $\mathrm{P}, \mathrm{mmol} / \mathrm{L}$ \\
\hline The first: clinically healthy $(\mathrm{n}=10)$ & $2.57 \pm 0.136$ & $1.68 \pm 0.176$ \\
The second experimental: bratislava, ballum $(\mathrm{n}=12)$ & $2.26 \pm 0.103$ & $1.40 \pm 0.154$ \\
The third experimental: kabura, polonica, szvajzak, & $2.34 \pm 0.050$ & $1.33 \pm 0.093$ \\
ballum, bratislava $(\mathrm{n}=14)$ & & \\
$\begin{array}{l}\text { The fourth experimental: } \text { kabura, polonica, ballum, } \\
\text { szvajzak, bratislava }(\mathrm{n}=9)\end{array}$ & $2.45 \pm 0.115$ & $1.31 \pm 0.078$ \\
\hline
\end{tabular}

\section{Discussion}

Leptospirosis is a quite dangerous natural-focal disease of animals and humans, which manifests in fever, icteritiousness of mucous membranes, hemoglobinuria, necrosis of the skin and mucous membranes (Ellis, 1990). During vital activity, Leptospira secrete aggressive substances and fibrinolysin, hyaluronidase, hemolysins, leucitinase, cytopathogenic factors, thermolabile and thermostable toxic substances. Leptospira have a tendency towards adhesion on the capillary endothelium and erythrocytes. Their influence leads to the development of capillary toxicosis, and in the future to universal hemorrhagic syndrome and the formation of degenerative and necrotic changes in many organs (Minova et al., 2009). According to the literature, at leptospirosis, disorders occurred in the functional state of the hepatobiliary and renal systems of horses (Holovakha, 2000), and pet animals (Kerr, 2005). In animals of other species, particularly cattle, this issue has not been sufficiently described (Sunder et al., 2017).

Since leptospirosis is quite severe disease, in clinical manifestations of which the prediction is always cautious, the objective of the study was changes in the biochemical parameters of blood in cows with leptospirosis according to the results of the reaction of microagglutination (RMA) (Olivera et al., 2018). In cows, antibodies to different serological groups were detected leptospirosis: bratislava 1:100, 1:200; ballum 1:100-1:200 (second experimental group); kabura 1:100-1:200; polonica 1:100; szvajzak 1:100-1:200; ballum 1:100; bratislava 1:100-1:200 (third experimental group); kabura 1:100; polonia 1:200; ballum 1:100; szvajzak 1:100-1:200; bratislava 1:800 (fourth experimental group).

It was determiined that in cows suffering leptospirosis, which was determined by RMA, changes in the blood manifest by hyperproteinemia as a result of increased biosynthesis of globulins in cellular elements of the system of mononuclear phagocytes during hepatopathy (Petrenko, 2015). Some animals, mostly in the fourth group, were observed to have hypoproteinemia, which indicates to disorder in the function of protein synthesis of hepatocytes. Its disorder was also indicated by dysproteinemia (disorder in the ratio between albumins and globulins), which was determined by coagulation tests - Greenstead and formaline tests. The largest number of cows with dysproteinemia was in the fourth and third groups. The final product of the cellular metabolism is ammonia $\left(\mathrm{NH}_{3}\right)$, which is a quite toxic product and is formed by the deamination of aminoacids, the destruction of purine and pyrimidine nucleotides. It is neutralized in periportal hepatocytes, becoming urea. The content of urea in the blood reflects the balance between the rate of its synthesis in hepatocytes and excretion through the kidneys with the urine. According to the researches, the level of urea in the blood in $50 \%$ of cows of the third and $44 \%$ of cows in the fourth experimental groups was reduced, indicating disorder of the urea-forming function of the liver. In infected cows with leptospirosis, anemia appears, which should be classified as hemolytic (enhanced destruction of erythrocytes). As a result of intensified hemolysis, the intensive formation of bilirubin out of hemoglobin occurs in the cells of the reticuloendothelial system. Instead, hepatocytes cannot conjugate large amounts of bilirubin, which leads to the accumulation of free pigment in blood and cells. The total bilirubin content was increased in $75.0 \%, 78.6 \%$ and $77.8 \%$ of cows, 
respectively. However, the ictericity of mucous membranes in infected cows was not observed, which indicates the large compensatory capacities of hepatocytes to conjugate bilirubin. Determination of the activity of enzymes in blood serum is of great importance in laboratory diagnostics of liver pathology. Enzymes are synthesized by hepatocytes and cells of the epithelium of bile ducts. They are divided into several groups, the main ones being an indicatory and excretory. Determination of indicatory enzymes is used in clinical practice for differential diagnosis of liver diseases and assessment of the degree of damage to the liver and the disorder of its functions. Diagnostic information is obtained by increasing the activity of indicator enzymes and their localization in hepatocytes. Alanine aminotransferase (ALAT) is found in the cytoplasm of hepatocytes, so increase in its activity indicates damage to the cytoplasmic membranes of the liver cells.

The highest activity of ALAT in cows of the fourth group (they were observed to have antibodies to serovars of kabura 1:100, polonica 1:200, ballum 1:100, szvajzak 1:100-1:200, bratislava 1:800), which indicates the damage to the cytoplasmic structures of hepatocytes.

Another asparagine aminotransferase (AST) is a mitochondrialcytoplasmic enzyme, and most of it is found in hepatocyte mitochondria. The liver of large cattle cointained the largest amount of AST.

It has been established that AST activity in cows suffering leptospirosis was increased. In particular, its activity in the second experimental group (by RMA - antibody titer - bratislava 1:100-1:200, ballum 1:100-1:200) was 1.93 times more compared to clinically healthy.

In the cows of the third experiment (serovars kabura 1:100-1:200, polonica 1:100, szvajzak 1:100-1:200, ballum 1:100-1:200, bratislava 1:100-1:200) and the fourth experimental groups (serovars kabura 1:100, polonica 1:200, ballum 1:100, szvajzak 1:100-1:200, bratislava 1:800) had an AST activity higher by 1.7 times compared to clinically healthy. Consequently, AST hyperenzymemia indicates severe damage to the energy potential of hepatocytes.

The lesion of the liver is accompanied by the development of cholestasis, to which the excretory enzymes (gamma-glutamyl transpeptidase (GGTP) and alkaline phosphatase (ALP)) react. These enzymes are membrane-binding and are located predominantly in the membranes near the biliary pole of hepatocytes (in the cell cytoplasm) or in the cells of the bile ducts. Therefore, increase in their activity in the blood occurs due to many diseases of the liver. And their hyperfermentemia does not always indicate cholestasis. Therefore, scientists are inclined to think that these excretory enzymes should be considered reactive rather than cholestatic. The activity of GGTP was on average increased in animals of all the three experimental groups. However, the largest number of animals with hyperenzymemia of GGTP (91.7\%) was found in the second group (serovars bratislava 1:100-1:200, ballum 1:100-1:200). The cows of this group had the highest values of the pigment - total bilirubin, which is a marker for the development of cholestasis syndrome. It should be noted that similar results of GGTP indicators were noted in cows of the third and fourth groups. Consequently, the increased activity of GGTP in cows under the latent course of leptospirosis indicates a prolonged pathological process in hepatocytes.

Unlike GGTP, alkaline phosphatase (ALP) is present in large quantities in the wall of the bile ducts and the determination of its total amount is a marker of the state of the biliary system. Therefore, cholestasis, as a cause of an increase in the activity of ALP in blood serum, develops at obstruction of the bile ducts, with disorders in the transport of bile at the level of small bile ducts. The increase in ALP activity also occurs when the liver is damaged due to its release of ALP from hepatocytes. The activity of the enzyme ALP, according to the results, was the highest in cows of the third group $(88.8 \%$ more than in clinically healthy). Values of ALP activity increased in cows during the latent course of the disease in the second group (according to RMA, serovars bratislava 1:100-1:200, ballum 1:100-1:200) and in cows of the fourth group (serovars kabura 1:100, polonica 1:200, ballum 1:100, szvajzak 1:100-1:200, bratislava 1:800).

The obtained biochemical results give grounds to assert that over latent course of leptospirosis the cows had manifestations of hepatopathy which should be classified as hepatocholangitis with the phenomena of intra- and extrahepatic cholestasis.
In cows during the latent course of leptospirosis, changes were also observed from the side of macroelement metabolism. This applies primarily to calcium and phosphorus. In cows of all experimental groups (second-fourth), hypocalcemia manifested. It was found in $66.7 \%$, $85.7 \%$, and $44.4 \%$ respectively.

Low levels of total calcium in the blood are associated with the metabolism of cholecalciferol, which in the intestine stimulates the synthesis of calcium-binding protein, which results in the binding of calcium that was introduced with fodder. Since cholecalciferol which is introduced with fodder is inactive, in the parenchymatous organs, in particular in hepatocytes in the mitochondrial apparatus, it transforms into 25hydroxyvitamin $\left[25(\mathrm{OH}) \mathrm{D}_{3}\right]$. And at liver damage, this metabolite is synthesized less and, accordingly, this intermediate product in insufficient amount transforms in $25(\mathrm{OH})_{2} \mathrm{D}_{3}$ or $24.25(\mathrm{OH})_{2} \mathrm{D}_{3} ; 1.25(\mathrm{OH})_{2} \mathrm{D}_{3}$ in the kidneys. As a result, calcium of binding protein for binding calcium in the intestine forms insufficiently. In addition to hypocalcemia, in cows with leptospirosis, hypophosphatemia (phosphorus content was less than $1.45 \mathrm{mmol} / \mathrm{L}$ ) appears. It was found in $66.7 \%, 64.3 \%$ and $66.7 \%$ of cows of the second-fourth group, due to a decrease in the metabolite of cholecalciferol $1.25(\mathrm{OH})_{2} \mathrm{D}_{3}$, which contributes to the absorption of phosphates from the intestines (Ellis, 2010).

\section{Conclusions}

Our research has shown that in cows of the black-spotted breed suffering leptospirosis, determined by the reaction of microagglutination (RMA), significant changes in the biochemical parameters of blood occurs, which indicates the development of hepatopathy. This process manifests in virtually all animals at the titer of antibodies to one or another serovar of Leptospira. In particular, cows at the titer of antibodies bratislava 1:100-1:200, ballum 1:100-1:200 were observed to have hyperproteinemia in $16.7 \%$ of animals, reduction of urea $(33.3 \%)$, hyperbilirubinemia $(75.0 \%)$, AST hyperenzymemia $(100 \%)$, GGTP (91.7\%), ALP (33.3\%), hypocalcemia, and hypophosphatemia in $66.7 \%$ of animals.

In animals, at the antibody titers of kabura 1:100-1:200, polonica 1:100, szvajzak 1:100-1:200, ballum 1:100-1:200, bratislava 1:100-1:200, there was observed hyperproteinemia in $42.9 \%$, dysproteinemia (according to the results of the Greenstead and formalin test, respectively, in $85.7 \%$ and $50.0 \%$ ), decrease in urea $(50.0 \%)$, hyperbilirubinemia (75.0\%), hyperenzymemia of AST (100\%), ALAT (14.3\%), GGTP (78.6\%), ALP (57.1\%), hypocalcemia $(78.6 \%)$, hypophosphatemia in $64.3 \%$ of animals.

In cows for the antibody titers kabura 1:100, polonica 1:200, ballum 1:100, szvajzak 1:100-1:200; bratislava 1:800, there was observed hyperproteinemia in $22.2 \%$, dysproteinemia (according to Greenstead and formalin test respectively, in $88.9 \%$ and $50.0 \%$, the latter in animals of this group was positive to sharply positive), urea decrease (44.4\%), hyperbilirubinemia (78.6\%), AST (100\%), ALAT (33.3\%), GGTP (77.8\%), ALP (55.6\%), hypocalcemia (44.4\%), and hypophosphatemia $(66.7 \%)$. The conducted studies indicate that, in addition to anisotropic therapy, when detecting leptospirosis in cows (by RMA), drugs should be prescribed that would contribute also to the restoration of the functional state of the hepatobiliary system.

\section{References}

Allan, K. J., Halliday, J. E. B., Moseley, M., Carter, R. W., Ahmed, A., Goris, M. G. A., Hartskeerl, R. A., Keyyu, J., Kibona, T., Maro, V. P., Maze, M. J., Mmbaga, B. T., Tarimo, R., Crump, J. A., \& Cleaveland, S. (2018). Assessment of animal hosts of pathogenic Leptospira in Northern Tanzania. PLoS Neglected Tropical Diseases, 12(6), 18.

Arent, Z. J., Andrews, S., Adamama-Moraitou, K., Gilmore, C., Pardali, D., \& Ellis, W. A. (2012). Emergence of novel Leptospira serovars: A need for adjusting vaccination policies for dogs? Epidemiology and Infection, 141(06), 1148-1153.

Ayral, F. C., Bicout, D. J., Pereira, H., Artois, M., \& Kodjo, A. (2014). Distribution of Leptospira serogroups in cattle herds and dogs in France. The American Journal of Tropical Medicine and Hygiene, 91(4), 756-759.

Campos, Â. P., Miranda, D. F. H., Rodrigues, H. W. S., da Silva Carneiro Lustosa, M., Martins, G. H. C., Mineiro, A. L. B. B., Castro, V., Azevedo, S. S., \& de Sousa Silva, S. M. M. (2017). Seroprevalence and risk factors for leptospiro- 
sis in cattle, sheep, and goats at consorted rearing from the State of Piauí, Northeastern Brazil. Tropical Animal Health and Production, 49(5), 899-907.

Chadsuthi, S., Chalvet-Monfray, K., Wiratsudakul, A., Suwancharoen, D., \& Cappelle, J. (2018). A remotely sensed flooding indicator associated with cattle and buffalo leptospirosis cases in Thailand 2011-2013. BMC Infectious Diseases, 18(1), 1-9.

Correia, L., Loureiro, A. P., \& Lilenbaum, W. (2018). Reduced susceptibility in leptospiral strains of bovine origin might impair antibiotic therapy. Epidemiology and Infection, 147, 5.

Daud, A., Fuzi, N. M. H. M., Arshad, M. M., Kamarudin, S., Mohammad, W. M. Z. W., Amran, F., \& Ismail, N. (2018). Leptospirosis seropositivity and its serovars among cattle in Northeastem Malaysia. Veterinary World, 11(6), 840-844.

Dreyfus, A., Wilson, P., Benschop, J., Collins-Emerson, J., Verdugo, C., \& Heuer, C. (2018). Seroprevalence and herd-level risk factors for seroprevalence of Leptospira spp. in sheep, beef cattle and deer in New Zealand. New Zealand Veterinary Journal, 66(6), 302-311.

Ellis, W. A. (1990). Leptospirosis: A review of veterinary aspects. Irish Veterinary News, 12, 6-12.

Ellis, W. A. (2010). Control of canine leptospirosis in Europe: Time for a change? Veterinary Record, 167(16), 602-605.

Ferrer de Morais, E. G., Magalhães, F. J. R., De Lima Filho, C. D. F., Brandespim, D. F., De Oliveira, P. R. F., Da Costa, D. F., De Azevedo, S. S., \& Mota, R. A. (2018). Geo-epidemiological study of Leptospira spp. infection in cattle, feral cats and rodents of the Fernando de Noronha Island, Brazil. Acta Scientiae Veterinariae, 46(1), 9

Guedes, I. B., Araújo, S. A. de A., de Souza, G. O., de Souza Silva, S. O., Taniwaki, S. A., Cortez, A., Brandão, P. E., \& Heinemann, M. B. (2019). Circulating Leptospira species identified in cattle of the Brazilian Amazon. Acta Tropica, $191,212-216$

Holovakha, V. I. (2000). Zminy hepatobiliarnoi systemy u konei pry infektsiini rynopnevmonii, leptospirozi ta stakhibotriotoksykozi [Changes in hepatobiliary system in horses with infectious rhinopneumonia, leptospirosis and stabiotrotoxicosis]. Visnyk Bilotserkivskoho Derzhavnoho Ahrarnoho Universytetu, 13(2), 49-54 (in Ukrainian).

Jaeger, L. H., Loureiro, A. P., \& Lilenbaum, W. (2018). VNTR analysis demonstrates new patterns and high genetic diversity of Leptospira sp. of animal origin in Brazil. Letters in Applied Microbiology, 67(2), 183-189.

Ko, A. I., Goarant, C., \& Picardeau, M. (2009). Leptospira: The dawn of the molecular genetics' era for an emerging zoonotic pathogen. Nature Reviews Microbiology, 7(10), 736-747.

Le Turnier, P., \& Epelboin, L. (2018). Mise au point sur la leptospirose. La Revue de Médecine Interne, 40(5), 306-312.

Libonati, H. A., Santos, G. B., Souza, G. N., Brandão, F. Z., \& Lilenbaum, W. (2018). Leptospirosis is strongly associated to estrus repetition on cattle. Tropical Animal Health and Production, 50(7), 1625-1629.

Martins, G., \& Lilenbaum, W. (2017). Control of bovine leptospirosis: Aspects for consideration in a tropical environment. Research in Veterinary Science, 112 , $156-160$

Martins, G., Oliveira, C. S., \& Lilenbaum, W. (2018). Dynamics of humoral response in naturally-infected cattle after vaccination against leptospirosis. Acta Tropica, 187, 87-91.

Minova, L. V., Chegunov, P. V., \& Matjash, V. I. (2009). Kliniko-patogeneticheskie mehanizmy ostroj pochechnoj nedostatochnosti [Clinical and pathogenetic mechanisms of acute renal failure]. Health of Ukraine, 3(2), 18-24 (in Russian).

Mughini-Gras, L., Bonfanti, L., Natale, A., Comin, A., Ferronato, A., La Greca, E., Patregnani, T., Lucchese, L., \& Marangon, S. (2013). Application of an integrated outbreak management plan for the control of leptospirosis in dairy cattle herds. Epidemiology and Infection, 142(06), 1172-1181.

Olivera, M., Chaparro, J. J., Chaparro, Y., Piedrahita, D., Fernández-Silva, J., Londoño, J., Palacio, L. G., Ramírez-Vásquez, N., \& Fernández-Silva, J. (2018) Cross sectional study of 13 Leptospira serovars in a Colombian dairy region. Revista Colombiana de Ciencias Pecuarias, 31(1), 10-16.

Petrenko, A. (2015). Liver and kidney function in dogs afflicted with various Leptospira serovar. Scientific Messenger of LNU of Veterinary Medicine and Biotechnologies. Series: Veterinary Sciences, 17(2), 177-183 (in Ukrainian).

Picardeau, M. (2017). Virulence of the zoonotic agent of leptospirosis: Still terra incognita? Nature Reviews Microbiology, 15(5), 297-307.

Pinna, M. H., Martins, G., Loureiro, A. P., \& Lilenbaum, W. (2018). Detection of bovine carriers of Leptospira by serological, bacteriological, and molecular tools. Tropical Animal Health and Production, 50(4), 883-888.

Pratt, N., Conan, A., \& Rajeev, S. (2017). Leptospira seroprevalence in domestic dogs and cats on the Caribbean Island of Saint Kitts. Veterinary Medicine International, 2017, 1-6.

Rajala, E. L., Sattorov, N., Boqvist, S., \& Magnusson, U. (2017). Bovine leptospirosis in urban and peri-urban dairy farming in low-income countries: A "One Health" issue? Acta Veterinaria Scandinavica, 59(1), 1-4

Reichel, M. P., Wahl, L. C., \& Hill, F. I. (2018). Review of diagnostic procedures and approaches to infectious causes of reproductive failures of cattle in Australia and New Zealand. Frontiers in Veterinary Science, 5, 1-15.

Rocha, B. R., Balaro, M., Pereira, P. V., Martins, G., \& Lilenbaum, W. (2018). Chronic experimental genital leptospirosis with autochthonous Leptospira santarosai strains of serogroup Sejroe. Small Ruminant Research, 164, 28-31.

Shiokawa, K., Welcome, S., Kenig, M., Lim, B., \& Rajeev, S. (2019). Epidemiology of Leptospira infection in livestock species in Saint Kitts. Tropical Animal Health and Production, 2019, 1-6.

Shrestha, R., McKenzie, J. S., Gautam, M., Adhikary, R., Pandey, K., Koirala, P., Miller, L. C., Collins-Emerson, J., Craig, S. B., Shrestha, S, \& Heuer, C. (2018) Determinants of clinical leptospirosis in Nepal. Zoonoses and Public Health, 65(8), 972-983.

Subharat, S., Wilson, P., Heuer, C., \& Collins-Emerson, J. (2012). Longitudina serological survey and herd-level risk factors for Leptospira spp. serovars Hardjo-bovis and Pomona on deer farms with sheep and/or beef cattle. New Zealand Veterinary Journal, 60(4), 215-222.

Sunder, J., Sujatha, T., Kundu, A., \& Kundu, M. S. (2017). Carrier status and seroprevalence of leptospirosis in cattle of South Andaman. Indian Journal of Animal Research, 52(1), 140-143.

Tagliabue, S., Figarolli, B. M., D'Incau, M., Foschi, G., Gennero, M. S., Giordani, R., Natale, A., Papa, P., Ponti, N., Scaltrito, D., Spadari, L., Vesco, G., \& Ruocco, L. (2016). Serological surveillance of leptospirosis in Italy: Twoyear national data (2010-2011). Veterinaria Italiana, 52(2), 129-138.

Ukhovskyi, V. V., Vydayko, N. B., Aliekseieva, G. B., Bezymennyi, M. V., Polupan, I. M., \& Kolesnikova, I. P. (2018). Comparative analysis of incidence of leptospirosis among farm animals and humans in Ukraine. Regulatory Mechanisms in Biosystems, 9(3), 409-416.

Zarantonelli, L, Suanes, A, Meny, P., Buroni, F, Nieves, C, Salaberry, X, Briano, C., Ashfield, N., Da Silva Silveira, C., Dutra, F., Easton, C., Fraga, M., Giannitti, F., Hamond, C., Macías-Rioseco, M., Menéndez, C., Mortola, A., Picardeau, M., Quintero, J., Ríos, C., Rodríguez, V., Romero, A., Varela, G., Rivero, R., Schelotto, F., Riet-Correa, F., \& Buschiazzo, A. (2018). Isolation of pathogenic Leptospira strains from naturally infected cattle in Uruguay reveals high serovar diversity, and uncovers a relevant risk for human leptospirosis. PLoS Neglected Tropical Diseases, 12(9), e0006694. 